\title{
Penerapan Model Discovery Learning Berbantuan Media Audiovisual Berbasis Pembelajaran Daring untuk Meningkatkan Hasil Belajar Siswa Kelas V SD 3 Cranggang Kabupaten Kudus
}

\author{
Siti Maghfiroh*, Widya Kusumaningsih, Fransiska Suciana \\ PPG Prajabatan, FIP, Universitas PGRI Semarang \\ *Corresponding Author. Email: wayansuada.tolai@gmail.com
}

\begin{abstract}
The purpose of this study was to describe the improvement in learning outcomes of grade 5 elementary school students on theme 8 by applying the Discovery learning model assisted by audiovisual media. The research method used is classroom action research which is carried out in 3 cycles. Each cycle is carried out in 4 (four) stages, namely the planning, implementation, observation, and reflection stages. The subjects of this study were fifth grade students of SD 3 Cranggang. Data collection techniques by means of interviews, observations, tests, and documentation. While the data analysis technique used is descriptive qualitative and quantitative analysis. The results of this study indicate that the application of discovery learning learning models with audiovisual media can improve the learning outcomes of fifth grade students at SD 3 Cranggang on the theme 8 Neighborhoods of Our Friends, where the results of this increase are proven in each research cycle.
\end{abstract}

Abstrak: Tujuan penelitian ini adalah untuk mendeskripsikan peningkatan hasi belajar siswa kelas kelas 5 SD pada tema 8 dengan menerapkan model pembelajaran Dicovery berbantuan media audiovisual. Metode penelitian yang digunakan adalah penelitian tindakan kelas yang dilaksanakan dalam 3 siklus. Setiap siklus dilakukan dalam 4 (empat) tahap, yaitu tahap perencanaan, pelaksanaan, pengamatan, dan refleksi. Subyek penelitian ini adalah siswa kelas V SD 3 Cranggang. Teknik pengumpulan data dengan cara wawancara, observasi, tes, dan dokumentasi. Sedangkan teknik analisis data yang digunakan adalah analisis deskriptif kualitatif dan kuantitatif. Hasil penelitian ini menunjukkan bahwa penerapan model pembelajaran discovery learning dengan media audiovisual dapat meningkatkan hasil belajar siswa kelas V SD 3 Cranggang pada tema 8 Lingkungan Sahabat Kita, dimana hasil peningkatan ini dibuktikan dalam setiap siklus penelitiannya.

\section{Article History}

Received: 27-05-2021

Revised: 11-06-2021

Accepted: 25-06-2021

Published: 07-07-2021

\section{Key Words:}

Discovery Learning,

Audiovisual Media,

Learning Outcomes,

\section{Sejarah Artikel \\ Diterima: 27-05-2021 \\ Direvisi: 11-06-2021 \\ Disetujui: 25-06-2021 \\ Diterbitkan: 07-07-2021}

\section{Kata Kunci: \\ Discovery Learning, Media Audiovisual, Hasil Belajar.}

How to Cite: Maghfiroh, S., Kusumaningsih, W., \& Suciana, F. (2021). Penerapan Model Discovery Learning Berbantuan Media Audiovisual Berbasis Pembelajaran Daring untuk Meningkatkan Hasil Belajar Siswa Kelas V SD 3 Cranggang Kabupaten Kudus. Jurnal Paedagogy, 8(3), 438-446. doi:https://doi.org/10.33394/jp.v8i3.3908

dC. https://doi.org/10.33394/jp.v8i2.3480

This is an open-access article under the CC-BY-SA License.

\section{Pendahuluan}

Tingkat kemajuan dari suatu bangsa dapat dilihat dari sektor pendidikannya. Pendidikan adalah suatu kebutuhan yang mendasar untuk dimiliki oleh setiap manusia agar dapat menciptakan sumber daya manusia yang berkualitas. Seseorang yang berpendidikan akan dapat membantu kemajuan bangsa dan negara menjadi lebih berkembang. Berdasarkan Undang-Undang Sisdiknas No. 20 Tahun 2003 pasal 1, pendidikan adalah usaha sadar dan terencana untuk mewujudkan suasana belajar dan proses pembelajaran agar peserta didik secara aktif mengembangkan potensi dirinya untuk memiliki kekuatan spiritual keagamaan, pengendalian diri, kepribadian, kecerdasan, akhlak mulia, serta keterampilan yang diperlukan dirinya, masyarakat, bangsa dan negara. Pendidikan di Indonesia menetapkan standar 
nasional untuk mewujudkan tujuan pendidikan nasional. Standar nasional pendidikan memuat kriteria minimal tentang komponen pendidikan yang memungkinkan setiap jenjang dan jalur pendidikan mengembangkan pendidikan secara optimal sesuai dengan karakteristik dan kekhasan programnya. Standar nasional pendidikan meliputi standar isi, standar proses, standar kompetensi lulusan, standar pendidik dan tenaga kependidikan, standar sarana dan prasarana, standar pengelolaan, standar pembiayaan, dan standar penilaian pendidikan (BSNP, 2006).

Dalam suatu sistem pendidikan agar tujuan pendidikan dapat tercapai sesuai dengan rencana maka dibutuhkan suatu peraturan mengenai pendidikan itu sendiri yang disebut kurikulum. Pada Peraturan Pemerintah Nomor 19 Tahun 2005 menyatakan bahwa "Kurikulum adalah seperangkat rencana dan pengaturan mengenai tujuan, isi, dan bahan pelajaran serta cara yang digunakan untuk mencapai tujuan pendidikan tertentu". Kurikulum untuk jenis pendidikan umum, kejuruan, dan khusus pada jenjang pendidikan dasar dan menengah terdiri atas lima kelompok mata pelajaran yaitu: a) kelompok mata pelajaran agama dan akhlak mulia; b) kelompok mata pelajaran kewarganegaraan dan kepribadian; c) kelompok mata pelajaran ilmu pengetahuan dan teknologi; d) kelompok mata pelajaran estetika; e) kelompok mata pelajaran jasmani, olah raga dan kesehatan. Kurikulum dan silabus SD/MI/SDLB/Paket A, atau bentuk lain yang sederajat menekankan pentingnya kemampuan dan kegemaran membaca dan menulis, kecakapan berhitung, serta kemampuan berkomunikasi. Kelompok mata pelajaran ilmu pengetahuan dan teknologi pada $\mathrm{SD} / \mathrm{MI} / \mathrm{SDLB} /$ Paket A, atau bentuk lain yang sederajat dilaksanakan melalui muatan dan/atau kegiatan bahasa, matematika, ilmu pengetahuan alam, ilmu pengetahuan sosial, keterampilan/kejuruan, dan muatan lokal yang relevan.

Dewasa ini, proses pembelajaran di jenjang SD/MI telah mengacu pada kurikulum 2013. Majid (2014) berpendapat bahwa, pembelajaran kurikulum 2013 adalah pembelajaran yang dirancang berdasarkan tema-tema tertentu yang dalam pembahasannya tema itu ditinjau dari berbagai mata pelajaran. Pembelajaran pada kurikulum 2013 berlandaskan pada filsafat progresivisme, konstruktivisme, dan humanisme. Pada hakikatnya, proses pembelajaran lebih menekankan pada keterlibatan peserta didik secara aktif. Di samping itu, proses pembelajaran lebih berorientasi pada penerapan konsep belajar sambil melakukan (learning by doing), mengedepankan pengalaman personal melalui proses mengamati, menanya, menalar, mengasosiasi, dan mengkomunikasikan untuk meningkatkan kreativitassiswa.Melalui pembelajaran ini, peserta didik dapat mencapai keseimbangan antara soft skills dan hard skills yang meliputi aspek kompetensi spiritual, sosial, pengetahuan, dan keterampilan.

Berdasarkan hasil observasi di SD 3 Cranggang Kudus diperoleh data nilai rata-rata harian siswa rendah dan belum mencapai KKM dari 13 siswa hanya 6 siswa $(46,16 \%)$ tuntas dan 7 siswa $(53,84 \%)$ tidak tuntas. Hal ini dikarenakan pembelajaran daring hanya dilakukan dengan pemberian dan penyelesaian tugas tanpa adanya refleksi, pembentukan pemahaman dan kebermaknaan materi pelajaran kepada peserta didik. Pembelajaran kurang menggunakan model dan media pembelajaran yang interaktif dan efektif karena pembelajaran daring hanya dilakukan secara satu arah dengan pemberian tugas melalui WA grup kelas dan kurang memanfaatkan platform daring seperti zoom meet, google meet, dan lain lain.

Salah satu model pembelajaran yang dapat mengatasi masalah tersebut adalah dengan menerapkan model pembelajaran Discovery Learning. Discovery learning merupakan model yang mengarahkan siswa menemukan konsep melalui berbagai informasi atau data yang diperoleh melalui pengamatan atau percobaan. Menurut Sani (2014), discovery learning merupakan proses dari inkuiri. Discovery learning adalah metode belajar yang menuntut guru 
lebih kreatif menciptakan situasi yang membuat peserta didik belajar aktif dan menemukan pengetahuan sendiri. Maharani \& Hardini (2017), Nurmiati (2020), Nuryaningsih (2021), dan Setiarini (2016) menjelaskan bahwa discovery learning adalah proses pembelajaran yang penyampaian materinya tidak utuh, karena model discovery learning menuntut siswa terlibat aktif dalam proses pembelajaran dan menemukan sendiri suatu konsep pembelajaran. Ciri utama model discovery learning adalah (1) berpusat pada siswa; (2) mengeksplorasi dan memecahkan masalah untuk menciptakan, menghubungkan, dan menggeneralisasi pengetahuan; serta (3) kegiatan untuk menggabungkan pengetahuan baru dan pengetahuan yang sudah ada (Kristin, 2016). Selanjutnya Darmadi (2017) menyebutkan langkah-langkah pengaplikasian model discovery learning yaitu (1) menentukan tujuan pembelajaran; (2) melakukan identifikasi karakteristik siswa; (3) menentukan materi pelajaran; (4) menentukan topik-topik yang harus dipelajari siswa secara induktif; (5) mengembangkan bahan-bahan dengan memberikan contoh, ilustrasi, tugas, dan sebagainya untuk dipelajari siswa; (6) mengatur topik-topik pelajaran berawal dari yang sederhana ke yang kompleks, dari yang konkret ke abstrak, dan dari tahap enaktif, ikonik sampai ke tahap simbolik; serta (7) melakukan penilaian proses dan hasil belajar siswa. Syah (dalam Darmadi, 2017) terdapat prosedur yang harus digunakan dalam mengaplikasikan model discovery learning, yaitu (a) stimulation (pemberian rangsangan); (b) problem statement (identifikasi masalah); (c) data collection (pengumpulan data); (d) data processing (pengolahan data); (e) verification (pembuktian); dan (f) generalization (menarik kesimpulan)

Selain penerapan model pembelajaran yang interaktif, pembelajaran akan lebih bermakna dan optimal apabila disertai dengan media pembelajaran yang sesuai dan inovatif. Media pembelajaran tidak hanya berupa alat atau bahan, tetapi juga hal-hal lain yang memungkinkan peserta didik untuk memperoleh pengetahuan. Media pembelajaran yang dapat digunakan untuk mendukung model discovery learning adalah media audiovisual. Media audiovisual yang digunakan berupa video. Media audiovisual merupakan media yang memungkinkan seseorang tidak hanya dapat melihat atau mengamati sesuatu, melainkan sekaligus dapat mendengar sesuatu yang divisualisasikan (Anitah, 2010). Hamdani (2011) menyatakan bahwa media audiovisual merupakan kombinasi audio dan visual atau bisa disebut media pandang-dengar. Audiovisual akan menjadikan penyajian bahan ajar kepada siswa semakin lengkap dan optimal. Selain itu, media ini dalam batas-batas tertentu dapat juga menggantikan peran dan tugas guru.

Model pembelajaran Discovery Learning dipilih menjadi solusi untuk mengatasi permasalahan pembelajaran tema VII kelas V SD 3 Cranggang dan mengacu pada beberapa penelitian yang telah dilakukan sebelumnya antara lain penelitian yang dilakukan oleh Cintia, Nichen Irma, dkk (2018) yang berjudul "Peningkatan Model Pembelajaran Discovery Learning untuk Meningkatkan Kemampuan Berpikir Kreatif dan Hasil Belajar Siswa". Hasil penelitiannya adalah Kondisi awal persentase kemampuan berpikir kreatif 33,2\% skor ratarata 13,3. Ketuntasan hasil belajar 38\% rata-rata 60 nilai tertinggi 72,5 dan terendah 45 . Siklus I, kemampuan berpikir kreatif siswa 73\%, skor rata-rata 29,2. Persentase hasil belajar $71,8 \%$, rata-rata 69,48 , nilai tertinggi 82,5 dan terendah 50. Siklus II, persentase kemampuan berpikir kreatif $81,2 \%$, rata-rata 32,2 . Hasil belajar $84,6 \%$, rata-rata 74,2 , nilai tertinggi 87,5 dan terendah 55. Dapat disimpulkan bahwa penerapan model Discovery Learning dapat meningkatkan kemampuan berpikir kreatif dan hasil belajar pembelajaran tematik siswa kelas V SDN Sidorejo Kidul 02 Tingkir.

Selanjutnya, penelitian yang mendukung dalam pemecahan masalah ini adalah penelitian yang dilakukan oleh Arum Perwitasari dan Zaenal Abidin (2014) dengan judul 
"Peningkatan Kualitas Pembelajaran PKn melalui Model Time Token Arends dengan Media Audio Visual". Hasil penelitiannya adalah Tingkat pencapaian keterampilan guru di siklus I memperoleh skor 21 dengan kategori baik, siklus II mendapat skor 24 kategori baik, siklus III mendapat skor 29 kategori sangat baik. Tingkat pencapaian aktivitas siswa siklus I mendapat skor 16,04 kategori cukup, siklus II mendapat skor 20,76 kategori baik, dan siklus III mendapat skor 24,64 dengan kategori baik. Tingkat pencapaian hasil belajar klasikal siswa siklus I sebesar 71,41\%, siklus II sebesar 79,48\% dan siklus III 89,74\%. Apabila dikaitkan dengan nilai KKM SDN Tambakaji 03 Semarang sebesar 63, maka nilai rata-rata siklus I, II, dan III sudah mencapai KKM. Sedangkan perolehan ketuntasan klasikal yang mencapai indikator keberhasilan $\geq 80 \%$ terpenuhi pada siklus III. Model Time Token Arends dengan media Audio Visual terbukti dapat meningkatkan kualitas pembelajaran PKn kelas V SDN Tambakaji 03 Semarang. Adapun penelitian ini bertujuan untuk mendeskripsikan peningkatan hasil belajar dengan penerapan model Discovery learning berbantuan media audiovisual pada tema 8 bagi siswa kelas V SD 3 Cranggang Kudus tahun ajaran 2020/2021.

\section{Metode Penelitian}

Penelitian ini menggunakan metode penelitian tindakan kelas, yakni dengan pendekatan kualitaf dan kuantitatif. Data kualitatif diperoleh dari lembar observasi dari setiap tindakan atau proses pembelajaran dan data kuantitatif diperoleh dari tes evaluasi pada setiap siklus (hasil pembelajaran). Pelaksanaan penelitian direncanakan dalam bentuk siklus. Masingmasing siklus dilaksanakan dengan empat tahap, yakni tahap perencanaan, tahap pelaksanaan, tahap observasi, dan tahap refleksi. Penelitian ini dilaksanakan di SD 3 Cranggang Kudus tahun pelajaran 2020/2021. Subjek penelitian ini adalah siswa kelas V berjumlah 13 siswa7 siswa perempuan dan 6 siswa laki-laki), yang berlangsung selama 6 pertemuan. Kriteria penilaian dalam menentukan keberhasilan siswa adalah nilai ketutasan individual mencapai KKM $\geq 70$ dan nilai ketuntasan belajar kelasikal mencapai $80 \%$

\section{Hasil Penelitian dan Pembahasan}

Hasil penelitian tindakan kelas menggunakan model discovery learning berbantuan media audiovisual diperoleh dari tes tertulis. Penelitian ini dilaksanakan dalam tiga siklus dengan dua kali pertemuan pada setiap siklusnya. Setiap pertemuan dilaksakan tes tertulis yang temuat dalam lembar soal evaluasi. Peneliti mendeskripsikan secara rinci data hasil penelitian mulai dari siklus I, siklus II, dan siklus III. Penelitian dilaksanakan dengan pembelajaran daring melalui aplikasi zoom meet sehingga guru tetap dapat bertemu secara virtual dengan siswa dan pembelajaran masih dapat terjadi secara dua arah. Kegiatan perbaikan pembelajaran dilakukan selama tiga kali dengan 2 kali pertemuan setiap siklus ini merupakan upaya untuk meningkatkan hasil belajar siswa pada tema 8 Lingkungan Sahabat Kita, sehingga tingkat penguasaan materi dan hasil belajar siswa akan meningkat. Hasil belajar dan tingkat ketuntasan belajar siswa kelas V semester II SD 3 Cranggang Kudus sebelum diadakan tindakan perbaikan pembelajaran masih sangat rendah, hal ini dapat dilihat dari nilai rata-rata hasil belajar (ulangan harian) dan tingkat ketuntasan belajar yaitu dari 13 siswa kelas $\mathrm{V}$ hanya 6 siswa atau 46,16\% yang telah tuntas belajar, sedangkan 7 siswa atau $53,84 \%$ lainnya tidak tuntas karena belum mencapai KKM yaitu 70 . 


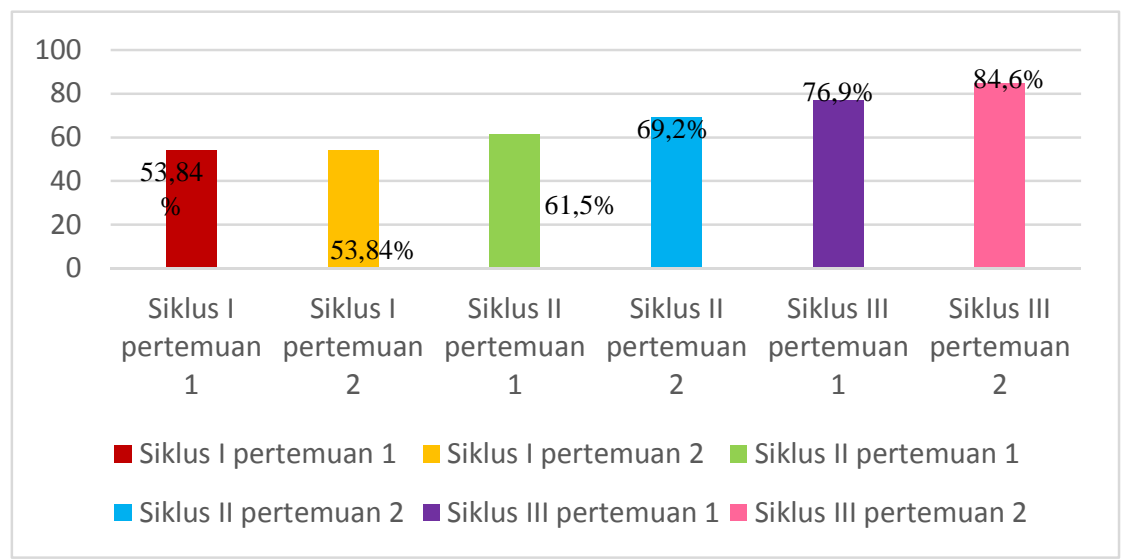

\section{Diagram 1. Ketuntasan belajar per siklus}

Berdasarkan data tersebut menunjukkan bahwa pelaksanaan pembelajaran yang dilakukan selama tiga siklus ini menunjukkan adanya peningkatan hasil belajar dan ketuntasan belajar sangat baik. Hasil dari analisis data diperoleh dalam pelaksanaan perbaikan yang dilakukan selama tiga siklus dapat digambarkan seperti pada table berikut:

Tabel 1. Nilai Rata-rata Per Siklus

\begin{tabular}{llcccccc}
\hline No. & Tahap Pembelajaran & Jml & \multicolumn{2}{c}{ Tuntas } & \multicolumn{2}{c}{ Belum tuntas } & Rata- \\
& & siswa & Jml & persentase & jml & persentase & rata \\
\hline 1 & Siklus I Pertemuan 1 & 13 & 7 & $53,84 \%$ & 6 & $46,16 \%$ & 65,38 \\
2 & Siklus I Pertemuan 2 & 13 & 7 & $53,84 \%$ & 6 & $46,16 \%$ & 68,1 \\
3 & Siklus II Pertemuan 1 & 13 & 8 & $61,50 \%$ & 5 & $38,50 \%$ & 71,9 \\
4 & Siklus II Pertemuan 2 & 13 & 9 & $69,20 \%$ & 4 & $30,80 \%$ & 73,1 \\
5 & Siklus III Pertemuan 1 & 13 & 10 & $76,90 \%$ & 3 & $23,10 \%$ & 75 \\
6 & Siklus III Pertemuan 2 & 13 & 11 & $84,60 \%$ & 2 & $15,40 \%$ & 82,3 \\
\hline
\end{tabular}

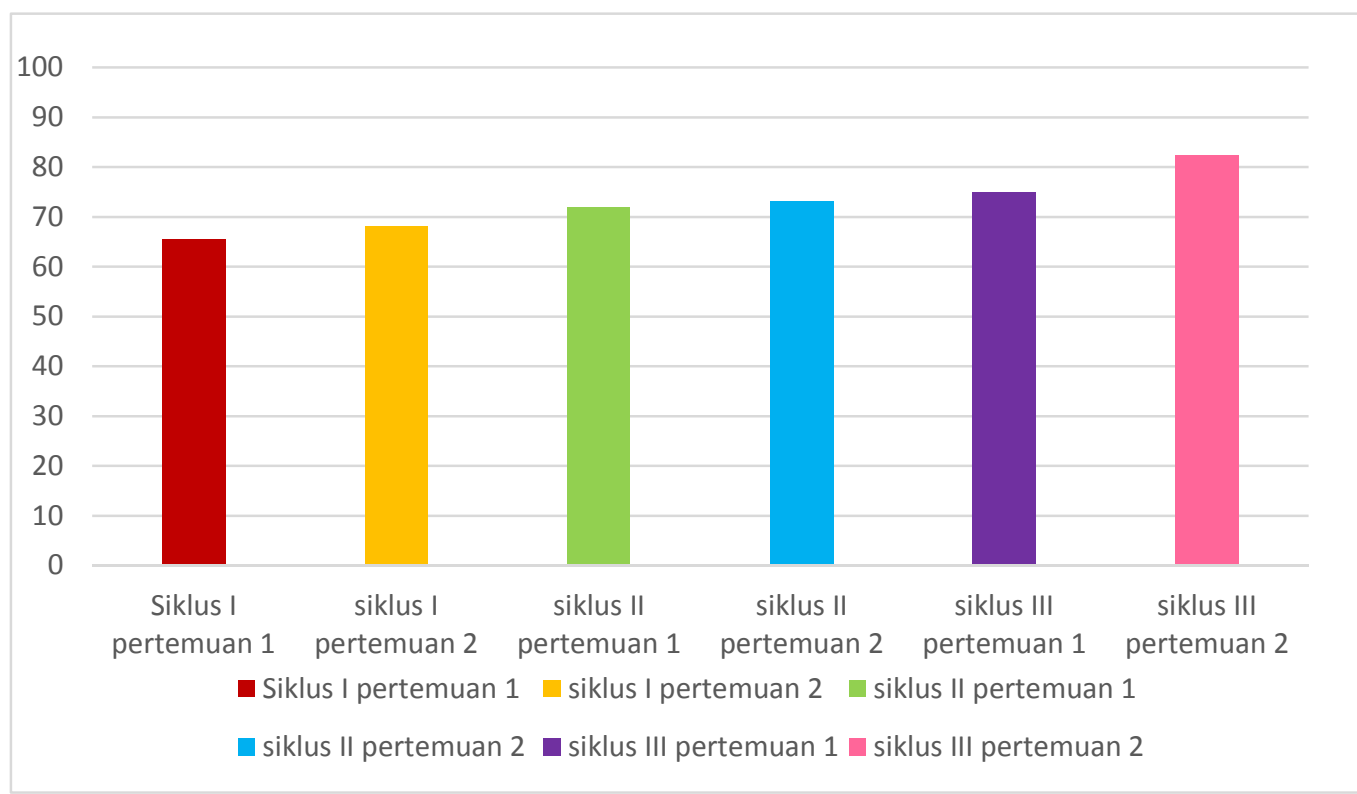

Diagram 2. Nilai rata-rata per siklus 


\section{Deskripsi Siklus I (Pertemuan 1)}

Sebelum melakukan kegiatan perbaikan pembelajaran, peneliti melakukan konsultasi dan diskusi dengan teman sejawat untuk mengadakan perencanaan dan persiapan kegiatan perbaikan pembelajaran dengan menyusun dan membuat perangkat atau komponenkomponen pembelajaran seperti RPP, Lembar observasi, Lembar evaluasi, LKPD, bahan ajar, media audiovisual, dll dengan sebaik-baiknya. Setelah diadakan perbaikan pembelajaran siklus I pertemuan 1 sesuai dengan apa yang telah direncanakan dan dipersiapkan, hasil belajar siswa pada siklus I pertemuan I mengalami kenaikan ketuntasan belajar di banding hasil sebelum perbaikan yaitu dari 6 atau 46.16\% siswa meningkat menjadi 7 siswa atau 53,84\% dari 13 siswa yang tuntas belajar pada siklus I pertemuan 1 dan saya serap 65,38\%. Dari hasil refleksi yang dilakukan oleh peneliti bersama dengan teman sejawat setelah melihat hasil tes evaluasi, hasil observasi, daya serap belum mencapai $>80 \%$ maka peneliti bersama teman sejawat memutuskan untuk melanjutkan kegiatan perbaikan lagi untuk pelaksanaan perbaikan pembelajaran siklus I pertemuan 2 dengan semua perangkat pembelajaran.

\section{Deskripsi Siklus I (Pertemuan 2)}

Sebelum melakukan kegiatan perbaikan pembelajaran siklus I pertemuan 2, peneliti melakukan konsultasi dan berdiskusi dengan teman sejawat untuk mengadakan perencanaan dan persiapan kegiatan perbaikan pembelajaran dengan menyusun dan membuat perangkat atau komponen-komponen pembelajaran seperti RPP, Lembar observasi, Lembar evaluasi, LKPD, bahan ajar, media audiovisual dengan mempertimbangkan hasil refleksi pada siklus I pertemuan 1. Setelah diadakan perbaikan pembelajaran siklus I pertemuan 2 sesuai dengan apa yang telah direncanakan dan dipersiapkan, ketuntasan hasil belajar siswa pada siklus I pertemuan 2 cukup baik dengan data 7 siswa (53,84\%) sudah tuntas sedangkan 6 siswa $(46,16 \%)$ tidak tuntas dan daya serap pembelajaran juga meningkat dari sebelumnya $65,38 \%$ (siklus I pertemuan 1) menjadi 68,1\%. Dari hasil refleksi yang dilakukan oleh peneliti bersama dengan teman sejawat setelah melihat hasil tes evaluasi, hasil observasi daya serap belum mencapai $>80 \%$ maka peneliti bersama teman sejawat memutuskan untuk melanjutkan kegiatan perbaikan lagi untuk pelaksanaan perbaikan pembelajaran siklus II pertemuan 1 dengan semua perangkat pembelajaran.

\section{Deskripsi Siklus II (Pertemuan 1)}

Sebelum melakukan kegiatan perbaikan pembelajaran siklus II pertemuan 1, peneliti melakukan konsultasi dan berdiskusi dengan teman sejawat untuk mengadakan perencanaan dan persiapan kegiatan perbaikan pembelajaran dengan menyusun dan membuat perangkat atau komponen-komponen pembelajaran seperti RPP, Lembar observasi, Lembar evaluasi, LKPD, bahan ajar, media audiovisual dengan mempertimbangkan hasil refleksi pada siklus I pertemuan 2. Setelah diadakan perbaikan pembelajaran siklus II pertemuan 1 sesuai dengan apa yang telah direncanakan dan dipersiapkan, ketuntasan hasil belajar siswa pada siklus II pertemuan 1 mengalami peningkatan dari siklus sebelumnya (siklus I pertemuan 2) yaitu 8 siswa $(61,5 \%)$ sudah tuntas sedangkan 5 siswa (38,5\%) tidak tuntas dan daya serap pembelajaran juga meningkat dari sebelumnya $68,1 \%$ (siklus I pertemuan 2) menjadi 71,9\%. Dari hasil refleksi yang dilakukan oleh peneliti bersama dengan teman sejawat setelah melihat hasil tes evaluasi, hasil observasi daya serap belum mencapai $>80 \%$ maka peneliti bersama teman sejawat memutuskan untuk melanjutkan kegiatan perbaikan lagi untuk pelaksanaan perbaikan pembelajaran siklus II pertemuan 2 dengan semua perangkat pembelajaran. 


\section{Deskripsi Siklus II (Pertemuan 2)}

Sebelum melakukan kegiatan perbaikan pembelajaran siklus II pertemuan 2, peneliti melakukan konsultasi dan berdiskusi dengan teman sejawat untuk mengadakan perencanaan dan persiapan kegiatan perbaikan pembelajaran dengan menyusun dan membuat perangkat atau komponen-komponen pembelajaran seperti RPP, Lembar observasi, Lembar evaluasi, LKPD, bahan ajar, media audiovisual dengan mempertimbangkan hasil refleksi pada siklus II pertemuan 1. Setelah diadakan perbaikan pembelajaran siklus II pertemuan 2 sesuai dengan apa yang telah direncanakan dan dipersiapkan, ketuntasan hasil belajar siswa pada siklus II pertemuan 2 mengalami peningkatan dari siklus sebelumnya (siklus II pertemuan 1) yaitu 9 siswa $(69,2 \%)$ sudah tuntas sedangkan 4 siswa $(30,8 \%)$ tidak tuntas dan daya serap pembelajaran juga meningkat dari sebelumnya $71,9 \%$ (siklus II pertemuan 1) menjadi $73,1 \%$. Dari hasil refleksi yang dilakukan oleh peneliti bersama dengan teman sejawat setelah melihat hasil tes evaluasi, hasil observasi daya serap belum mencapai $>80 \%$ maka peneliti bersama teman sejawat memutuskan untuk melanjutkan kegiatan perbaikan lagi untuk pelaksanaan perbaikan pembelajaran siklus III pertemuan 1 dengan semua perangkat pembelajaran.

\section{Deskripsi Siklus III (Pertemuan 1)}

Sebelum melakukan kegiatan perbaikan pembelajaran siklus III pertemuan 1, peneliti melakukan konsultasi dan berdiskusi dengan teman sejawat untuk mengadakan perencanaan dan persiapan kegiatan perbaikan pembelajaran dengan menyusun dan membuat perangkat atau komponen-komponen pembelajaran seperti RPP, Lembar observasi, Lembar evaluasi, LKPD, bahan ajar, media audiovisual dengan mempertimbangkan hasil refleksi pada siklus II pertemuan 2. Setelah diadakan perbaikan pembelajaran siklus III pertemuan 1 sesuai dengan apa yang telah direncanakan dan dipersiapkan, ketuntasan hasil belajar siswa pada siklus III pertemuan 1 mengalami peningkatan dari siklus sebelumnya (siklus II pertemuan 2) yaitu 10 siswa $(76,9 \%)$ sudah tuntas sedangkan 3 siswa $(23,1 \%)$ tidak tuntas dan daya serap pembelajaran juga meningkat dari sebelumnya $73,1 \%$ (siklus II pertemuan 2) menjadi $75 \%$. Dari hasil refleksi yang dilakukan oleh peneliti bersama dengan teman sejawat setelah melihat hasil tes evaluasi, hasil observasi daya serap belum mencapai $>80 \%$ maka peneliti bersama teman sejawat memutuskan untuk melanjutkan kegiatan perbaikan lagi untuk pelaksanaan perbaikan pembelajaran siklus III pertemuan 2 dengan semua perangkat pembelajaran.

\section{Deskripsi Siklus III (Pertemuan 2)}

Sebelum melakukan kegiatan perbaikan pembelajaran siklus III pertemuan 2, peneliti melakukan konsultasi dan berdiskusi dengan teman sejawat untuk mengadakan perencanaan dan persiapan kegiatan perbaikan pembelajaran dengan menyusun dan membuat perangkat atau komponen-komponen pembelajaran seperti RPP, Lembar observasi, Lembar evaluasi, LKPD, bahan ajar, media audiovisual dengan mempertimbangkan hasil refleksi pada siklus III pertemuan 1. Setelah diadakan perbaikan pembelajaran siklus III pertemuan 2 sesuai dengan apa yang telah direncanakan dan dipersiapkan, ketuntasan hasil belajar siswa pada siklus III pertemuan 2 mengalami peningkatan dari siklus sebelumnya (siklus III pertemuan 1) yaitu 11 siswa $(84,6 \%)$ sudah tuntas sedangkan 2 siswa $(15,4 \%)$ tidak tuntas dan daya serap pembelajaran juga meningkat dari sebelumnya $75 \%$ (siklus III pertemuan 1) menjadi $82,3 \%$. Dari hasil refleksi yang dilakukan oleh peneliti bersama dengan teman sejawat setelah melihat hasil tes evaluasi dan hasil observasi, maka peneliti memutuskan untuk mengakhiri kegiatan perbaikan pembelajaran sampai pada siklus III pertemuan 2. Hal ini karena daya serap telah sesuai degan kriteria keberhasilan tingkat ketutasan yaitu lebih dari $80 \%$. 
Meningkatnya hasil belajar kognitif siswa dari perbaikan pembelajaran yang telah dilaksanakan menunjukkan bahwa penggunaan model discovery learning dan media audiovisual dapat meningkatkan hasil belajar siswa pada tema 8 Lingkungan Sahabat kita bagi siswa kelas V SD 3 Cranggang Kudus tahun pelajaran 2020/2021.

\section{Kesimpulan}

Berdasarkan hasil penelitian tindakan kelas yang telah dilakukan melalui perbaikan pembelajaran yang dilaksanakan di kelas V SD 3 Cranggang tahun pelajaran 2020/2021 pada tema 8 Lingkungan Sahabat Kita dengan menggunakan model discovery learning berbantuan media audiovisual mengalami peningkatan hasil belajar dan ketuntasan belajar siswa. Hal tersebut dapat dilihat pada siklus I pertemuan 1 sebanyak 7 siswa $(53,84 \%)$ sudah tuntas 6 siswa $(46,16 \%)$ tidak tuntas dengan rata-rata hasil belajar 65,38. Pada siklus I pertemuan 2 sebanyak 7 siswa $(53,84 \%)$ sudah tuntas 6 siswa $(46,16 \%)$ tidak tuntas denga rata-rata hasil belajar 68,1. Pada siklus II pertemuan 1 sebanyak 8 siswa $(61,5 \%)$ sudah tuntas 5 siswa $(38,5 \%)$ tidak tuntas dengan rata-rata hasil belajar 71,9. Pada siklus II pertemuan 2 sebanyak 9 siswa $(69,2 \%)$ sudah tuntas 4 siswa $(30,8 \%)$ tidak tuntas dengan rata-rata hasil belajar 73,1 . Pada siklus III pertemuan 1 sebanyak 10 siswa $(76,9 \%)$ sudah tuntas 3 siswa $(23,1 \%)$ tidak tuntas dengan rata-rata hasil belajar 75. Pada siklus III pertemuan 2 sebanyak 11 siswa $(84,6 \%)$ sudah tuntas 2 siswa $(15,4 \%)$ tidak tuntas denga rata-rata hasil belajar 82,3.

\section{Saran}

Adapun saran yang dapat disampaikan berdasarkan hasil penelitian ini antara lain: (1) bagi guru: penerapan model discovery learning dengan berbantuan media audiovisual terbukti dapat meningkatkan kualitas pembelajaran tema 8 Lingkungan sahabat kita yaitu pada hasil belajar ranah kognitif siswa. Oleh karena itu, model pembelajaran discovery learning berbantuan media audiovisual dapat dijadikan acuan guru sebagai solusi peningkatan hasil belajar siswa pada tema yang lain. (2) bagi siswa: diharapkan siswa lebih aktif dalam pembelajaran menggunakan model discovery learning berbantuan media audiovisual sehingga hasil belajar yang dicapai dapat maksimal. (3) bagi sekolah/lembaga: penelitian penerapan model discovery learning berbantuan media audiovisual ini diharapkan dapat dikembangkan lebih lanju, baik oleh guru, lembaga, maupun pengembang pendidikan lainnya. Sehingga, model discovery learning berbantuan media audiovisual menjadi lebih baik serta tujuan pembelajaran semakin efektif dan efisien.

\section{Daftar Pustaka}

Abidin, Zaenal, dkk. (2014). Peningkatan Kualitas Pembelajaran PKn Melalui Model Time Token Arends dengan Media Audio Visual. Joyful Learning Journal Volume 3 No 1 Alwi, Idrus, dkk. (2014). Panduan Implementasi Kurikulum 2013 untuk Pendidik dan Tenaga Kependidikan. Jakarta: Saraz Publishing.

Anni, Catharina. (2010). Psikologi Pendidikan. Semarang: UPT MKK UNNES Arikunto, Suharsimi, dkk. (2006). Penelitian Tindakan Kelas. Jakarta: Bumi Aksara. Arsyad, Azhar. (2005). Media Pembelajaran. Jakarta: PT Raja Grafindo Persada BSNP. (2006). Standar Isi dan Standar Kompetensi Kelulusan untuk Satuan Pendidikan SD/MI. Jakarta: BP Cipta Jaya

Cintia, Nichen Irma, dkk. (2018). Penerapan Model Pembelajaran Discovery Learning untuk Meningkatkan Kemampuan Berpikir Kreatif dan Hasil Belajar Siswa. Journal Article 
Daryanto. (2010). Meida Pemnelajaran. Yogyakarta: Gaya Media

Depdiknas. (2003). Undang-undang RI No. 20 Tahun 2003 Tentang system pendidikan Nasional.

Hamdani. (2011). Strategi Belajar Mengajar. Bandung: Pustaka Setia

Hosnan, M. (2014). Pendekatan Saintifik dan Konstektual Dalam Pembelajaran Abad 21. Bogor: Ghalia Indonesia.

Maharani, B.Y, \& Hardini. (2017). Penerapan Model Pembelajaran Discovery Learning Berbantuan Benda Konkret Untuk Meningkatkan Hasil Belajar IPA. ejurnalmitrapendidikan. I (5). 549-561. Diakses dari laman web taggal 14 Juni 2020 dari: http://e-jurnalmitrapendidikan.com/index.php/CP/ejmp/article/view/106

Mulyasa. (2014). Guru dalam Implementasi Kurikulum 2013. Bandung: PT Remaja Rosda karya.

Nurmiati, B. (2020). Meningkatkan Motivasi dan Hasil Belajar Peserta Didik dengan Mengoptimalkan Penerapan Model Discovery Learning di SD Negeri 2 $\begin{array}{llll}\text { Cakranegara. Jurnal } & \text { Paedagogy, } & \text { 6(1), }\end{array}$ doi:https://doi.org/10.33394/jp.v6i1.2523

Nuryaningsih, W. (2021). Penerapan Model Discovery Learning Berkolaborasi Google Classroom dan WhatsApp Group untuk Meningkatkan Kompetensi Siswa dalam Menulis Teks Eksplanasi. Jurnal Paedagogy, $\quad 8(2), \quad$ 159-168. doi:https://doi.org/10.33394/jp.v8i2.3540

Sani, R. (2014). Pembelajaran saintifik untuk implementasi kurikulum 2013. Jakarta: PT. Bumi Aksara.

Saufi, I., \& Rizka, M. (2021). Analisis Pengaruh Media Pembelajaran Film Dokumenter Terhadap Motivasi Belajar Siswa. Jurnal Teknologi Pendidikan : Jurnal Penelitian dan Pengembangan Pembelajaran, 6(1), 55-59. doi:https://doi.org/10.33394/jtp.v6i1.3626

Setiarini, A. (2016). Meningkatkan Motivasi dan Hasil Belajar Peserta Didik dengan Mengoptimalkan Penerapan Pendekatan Saintifik Strategi Discovery Learning dan Metode Diskusi di SDN Model Mataram. Jurnal Kependidikan: Jurnal Hasil Penelitian dan Kajian Kepustakaan di Bidang Pendidikan, Pengajaran dan Pembelajaran, 2(1). doi:https://doi.org/10.33394/jk.v2i1.390

Suarni, G., Rizka, M., \& Zinnurain, Z. (2021). Analisis Pengaruh Penerapan Model Pembelajaran Sains Teknologi Masyarakat Terhadap Hasil Belajar Siswa. Jurnal Paedagogy, 8(1), 31-38. doi:https://doi.org/10.33394/jp.v8i1.3226

Sugiyono. (2017). Metode Penelitian Pendidikan Pendekatan Kuantitatif Kualitatif dan $R \& D$. Bandung: Alfabeta. 